\title{
Primórdios da vida judicial de São Leopoldo:! 0 Juiz de Paz e a sua atuação
}

The beginning of judicial life in São Leopoldo: the Justice of the Peace and its performance

Primeros años de São Leopoldo judicial: el Juez de Paz y su rendimiento

Caroline von Mühlen*

\section{Resumo}

A colônia alemã de São Leopoldo foi fundada na Antiga Real Feitoria do Linho Cânhamo, em 1824. A partir dessa data, a Colônia recebeu um contingente expressivo de imigrantes oriundos de diferentes Estados, Principados e GrãoDucados alemães. Essa diversidade representava um outro grupo social que deveria desenvolver a agricultura no sul do Brasil e configurar uma nova sociedade, a qual não era composta por alemães e seus descendentes, mas também por luso-brasileiros. Através da análise do Primeiro Livro de Juiz de Paz da Colônia Alemã de São Leopoldo, que abrange os anos de 1832 até 1845, observamos os motivos que levaram os moradores de São Leopoldo a procurar a Justiça.

Palavras-chave: Colônia Alemã de São Leopoldo. Primeiro Livro de Juiz de Paz. Justiça.
Em 1857, Luiza Wilborn, ${ }^{2}$ viúva de Peter Wilborn, ${ }^{3}$ move uma ação contra Felippe Schneider, ${ }^{4}$ alegando que esse havia levado todos os bens do casal para a sua casa. O finado deixa para Luiza e para o filho herdeiro Augusto "meia colônia sob número 1 na Picada dos Dois Irmãos e outros bens móveis". A outra metade da colônia foi vendida por $400 \$ 000$ (quatrocentos mil réis), valor entregue a Felippe Schneider, genro de Wilborn. No Primeiro Livro de Juiz de Paz de São Leopoldo, consta a informação de que no Doutoranda do Programa de Pós-Graduação em
História da PUCRS. Bolsista CNPq. Orientan-
da do Professor Doutor René Ernaini Gertz.

Recebido em 31/07/2013 Aprovado em 25/08/2013 http://dx.doi.org/10.5335/hdtv.14n.1.3691 
dia 20 de março de 1838, portanto dez anos antes do falecimento de Pedro Wilborn, o colono Gabriel Hatzenberger e sua mulher Ana Maria trocaram a sua colônia, localizada na Serra Grande (São Leopoldo) pela colônia de Pedro Wilborn e Felippe Schneider. Pedro e Felippe receberam ainda "quarenta mãos de milho que ficam na colônia" (HUNSCHE, 1979, p. 84 e 85).

Além da meia colônia, outros bens móveis e semoventes foram deixados com o pelo falecimento de Peter Wilborn. Destes, alguns

[...] se acham ainda em poder de Felippe Schneider: huma arma de fogo, duas pistolas, duas flautas, duas mezas grandes, dois bancos, quatro panelas de ferro, huma chaleira, huma trempe de ferro, huma frigideira, dois baldes de água, hum moinho de café, duas enxadas, dois machados, huma foice, duas correntes de ferro, huma dita de cobre, huma caixa de roupa, dois lansoles, seis facas de meza, oito pratos, seis tijelas, três pratos grandes, dois garrafone, duas colheres grandes de metal, huma peneira. ${ }^{5}$

Os bens estavam sob o poder de Schneider, pois, e logo após o falecimento do marido, a suplicante foi morar com o genro e a filha Carolina para onde levou todos os bens que adquirira ao longo do enlace matrimonial com Pedro Wilborn. Outros, no entanto, especialmente os bens semoventes já haviam sido vendidos pelo valor de $385 \$ 000$ (trezentos e oitenta e cinco mil réis). ${ }^{6}$

Em 1857, ano do processo, Luiza alega que Felippe utilizou meios fraudulentos para se apossar da meia colônia que ficara como herança para o filho Augusto, e que "a força tem botado a supp pe para fora da sua casa ficando todos os seus bens moveis e semoventes". Diante dessa situação, Lui- za solicita, em uma audiência, que o genro apresentasse "os seus documentos por onde mostre ser dono das terras que forcoza se quer apossar e não só desistir destas terras como também lhe entregar os bens moveis". Felippe, no entanto, apresentou o documento, no qual Pedro Wilborn entregou meia colônia como dote para a sua enteada e para o seu genro, o qual estava assinado e acordado por ambos. ${ }^{7}$

Fizerão o contracto seguinte entre Pedro Wilborn e sua mulher Luiza Ruppenthal, o qual declara que é de sua livre vontade que o seo marido fique sendo só senhor da meia colônia cituada na Picada dos Dois Irmãos a qual foi vendida pela quantia de cento e noventa e dois mil réis, cuja quantia pertence a elle, isto no caso que haja separação de bens e em recompensa disto fica sendo a sua mulher a senhora da quarta parte da colônia de que comprou o seu genro Felippe Schneider. ${ }^{8}$

Apesar de alegar que concede o dote à sua filha contra vontade e que não autorizou Augusto Rodolpho a assinar a declaração, pelo fato de não saber escrever, a autora da ação foi "condenada nas custas em três dobro e que os documentos oferecidos são suficientes para dispresar-se emlimine o libello". ${ }^{9}$ Isto é, Felippe foi absolvido da instância e garantiu a meia colônia e os bens do finado Peter Wilborn.

O processo descrito anteriormente integra um conjunto de 145 processos registrados no Primeiro Livro de Juiz de Paz de São Leopoldo. Esse processo revela, em certa medida, indícios das dificuldades que inúmeros imigrantes enfrentaram para adequar-se às leis e às normas impostas no local em que estavam inseridos, assim como a necessida- 
de de adaptação destes aos parcos recursos disponíveis no início do processo de colonização. Antes de continuarmos a análise do Primeiro Livro de Juiz de São Leopoldo, julgamos importante o leitor conhecer um pouco mais sobre a figura do Juiz de Paz.

Após a Independência do Brasil, em 1822 , havia a necessidade de organizar política, jurídica e economicamente o governo do Brasil. Politicamente independente de Portugal, estavam em voga mudanças que previam uma transição do antigo Regime Colonial para a implementação de um novo sistema jurídico-administrativo. Segundo Rodycz, "a primeira norma que dispôs sobre órgãos jurisdicionais no Brasil foi o Decreto de 18 de junho de 1822, que criou o corpo de juízes" (2003, p. 3). Esse juízo foi um importante marco no sistema judicial brasileiro, e favoreceu a criação do cargo de Juiz de Paz.

Foi nesse contexto de mudanças que se criou formalmente o Juizado de Paz no Brasil, através da Constituição outorgada em 1824, pelo Imperador D. Pedro, cujo objetivo era agilizar a justiça. Para Alexandra Coda (2010, p. 1), a Constituição Imperial de 1824 foi o "pontapé" inicial, não para romper com as normas e condutas, mas para a criação de um Estado capaz de regular o seu território e desvincular-se, oficialmente, de Portugal. Assim, a Constituição Imperial, regida pelo Código Criminal do Império e pelo Código de Processo Criminal, contribuiu para promover a transição do Regime Colonial para o Império, bem como, para reduzir os poderes do Imperador. Joelma Aparecida Nascimento (2011, p. 2) destaca em seu artigo “Herança e adaptação em uma vila do Império: juízes de paz, diversidade econômica e hierarquias sociais. Mariana, Brasil (1827-1841)" que a criação do cargo de Juiz de Paz girava em torno de dois eixos: uma estrutura jurídica colonial deficitária e atrasada; e a necessidade de implementação da justiça no Brasil. É nesse sentido que a justiça passa a ser um dos pilares a serem organizados, pois havia a necessidade de agilizar os processos judiciais e resolver os conflitos locais, devido à falta de profissionais letrados (VELLASCO, 2004, p. 99).

A regulamentação do Juizado de Paz ocorre somente em 1827, quando, por meio da Lei Orgânica de 15 de outubro de 1827, se estabeleceu a obrigatoriedade de um Juiz de Paz para realizar a conciliação das partes nos processos judiciais. Dessa forma, o cargo de Juiz de Paz, a partir dessa data, torna-se a estrutura judicial apontada como a primeira grande reforma judicial, com a qual se pretendia acabar com as práticas absolutistas na magistratura (CODA, 2010, p. 2). Essa lei promoveu a substituição dos antigos cargos de Juiz de Fora ou Ouvidor pelo cargo de Juiz de Paz, Juiz Municipal, ${ }^{10}$ de Direito ${ }^{11}$ e de Promotor Público. ${ }^{12}$ Com essa mudança pretendia-se inserir o Brasil independente num moderno e liberal conjunto de leis, na qual o objetivo era agilizar e melhorar as decisões no Brasil (CODA, 2010, p. 2). O Juiz de Paz também passou a ser responsável por funções que antes eram exercidas pelos Juízes Ordinários e Almotacés.

Para Rudycz (2003, p. 10),

[...] o juiz de paz tornou-se forte porque não dependia do poder do rei, como o juiz de fora ou o ouvidor; por ser eletivo, seu poder provinha do eleitorado. Essa importância se revela na competência que lhe 
foi atribuída, que era superior inclusive à dos juízes de fora - que eram profissionais, nomeados pela Coroa. Por esse motivo, desde o princípio houve conflitos entre esses dois juízes. Os letrados tiveram seu orgulho corporativo ofendido ao ter que compartilhar sua autoridade com juízes não profissionais. Em verdade, Juiz de Paz enfeixava ainda as competências de outros três juízes coloniais: o juiz ordinário, o juiz de vintena e o almotacé: “o juiz de paz representou uma tentativa de revitalizar a administração local, resgatando os poderes de três instituições portuguesas moribundas, reunindo-os nas mãos de um único magistrado, mais poderoso".

Pela Lei de 1827 , artigo $3^{\circ}$, podia exercer o cargo de Juiz de Paz "todo aquele que pudesse ser eleitor". Já o artigo 94 da Constituição do Império determinava que

[...] eleitores eram aqueles que tivessem renda líquida anual não inferior a 200\$000 (duzentos mil réis) por bens de raiz, indústria, comércio ou emprego; ter idade de 21 anos, exceto se for bacharel formado ou clérigo de ordens sacras, e deveria saber ler e escrever (NASCIMENTO, 2010a, p. 160).

Depois de escolhido o Juiz de Paz, este

[...] deveria ter um escrivão, nomeado e juramentado pela Câmara Municipal; ter os mesmos emolumentos que o Juiz de Direito e o produto das multas impostas por ele seria aplicada às despesas das Câmaras (NASCIMENTO, 2010a, p. 160).

Cabe destacar que entre 1827 a 1840 ocorrem inúmeras mudanças e alterações no Juizado de Paz. A Lei de 1827, por exemplo, permitia ao Juiz de Paz julgar causas civis de até $16 \$ 000$ (dezesseis mil réis), realizar corpo de delito, conceder fiança, manter a ordem, prender bêbados e delinquentes e interrogar os detidos. A Lei de 1828, por sua vez, incluía à competência do Juiz de Paz julgar as multas de infrações às posturas municipais. O Decreto de 1830 aboliu o cargo de almotacé e repassou suas atribuições ao Juiz de Paz. O Código de Processo Criminal de $1832^{13}$ incluia às atribuições do Juiz de Paz, o julgamento de pequenos crimes. É a Lei de 3 de dezembro de 1841, que transferiu para os Juízes Municipais, Chefes de polícia e Delegados as atribuições criminais antes realizada pelo Juiz de Paz. A partir dessa data, ficava a cargo do Juiz de Paz somente os aspectos notoriais (BAZÍLIO, 2012, p. 64-65).

A Lei de $1^{\circ}$ de outubro de 1828 definiu a forma pela qual se realizaria a eleição dos Membros das Câmaras Municipais. Tal regramento legal determinou que o candidato aos cargos de Vereador, de Juiz de Paz e de suplente deveria inscrever-se quinze dias antes das eleições. Estabeleceu, ainda, que as eleições para esses cargos fossem realizadas de quatro em quatro anos, de acordo com os editais afixados na porta das Igrejas das vilas e das cidades pelo Juiz de Paz (NASCIMENTO, 2010a, p. 62). Somente podia candidatar-se aos cargos de Vereador, Juiz de Paz e suplente aquele cidadão que não tivesse inimizade com o governo, não fosse contrário ao sistema constitucional estabelecido, além de ser "homem probo e honrado".

Em cada freguesia ou paróquia, devia haver um Juiz de Paz e um suplente. Eram eleitos ao mesmo tempo e maneira por que se elegiam os vereadores. Não se admitia recusa, a não ser por motivo de moléstia ou emprego cujo exercício conjunto fosse impossível (RUDYCZ, 2003, p. 7).

É importante salientar que era também o Juiz de Paz que presidia as eleições, antes executadas pelo Presidente da Câmara. 
Até 1832, elegia-se um Juiz de Paz e um suplente, conforme previa a Lei de 15 de outubro de 1827. Com a promulgação do Código de Processo Criminal, em 1832, concedeu-se ao Juiz de Paz o poder de administrar a Justiça nos Distritos de Paz e as eleições deveriam ser realizadas de quatro em quatro anos. Entretanto, permitia-se a eleição de quatro Juízes, os quatro cidadãos mais votados, seguindo a ordem de votos, assumiriam as funções cada um em um ano do quatriênio no Distrito de Paz. Os quatro cidadãos seguintes da lista de mais votados assumiriam o cargo de suplente, respectivamente com o Juiz de Paz.

O cargo de juiz de paz foi originalmente concebido para ser ocupado por magistrados leigos, sem necessidade de formação jurídica ou conhecimento das leis; eleitos conjuntamente e de forma semelhante aos vereadores da Câmara, em caráter de voluntariedade (CODA, 2010, p. 2).

Nesse sentido, a criação do cargo de Juiz de Paz é resultado das transformações que ocorriam no país e uma tentativa de caráter liberal, na qual se desejava promover a descentralização do poder e organizar a justiça brasileira.

Era escolhido de forma eletiva, possuía poderes de vigilância sobre a jurisdição, era leigo, mas reconhecido na localidade. Depois de escolhido, o Juiz de Paz era encarregado, simultaneamente, por atribuições judiciais ${ }^{14}$, administrativas ${ }^{15}$ e policiais. ${ }^{16}$ "Sua primeira e principal função era promover conciliações entre as partes envolvidas em litígios em potencial, entretanto, várias outras funções foram sendo-lhes atribuídas [...]" (CODA, 2010, p. 2). A conciliação entre as partes não era obrigatória, mas tinha força de lei, caso ocorresse. O Juiz de Paz deveria citar as pessoas que pretendiam iniciar o processo para que pessoalmente pudessem discutir sobre a causa. $\mathrm{O}$ valor não podia ultrapassar de $16 \$ 000$ (dezesseis mil réis). Caso não ocorresse a conciliação, os autos seguiam ao Juiz competente (RUDYCZ, 2003, p. 11).

Era de competência do Juiz de Paz,

[...] conciliar as partes antes da demanda, processar e julgar as causas cíveis cujo valor não excedesse a dezesseis mil-réis; manter a ordem nos ajuntamentos (reuniões públicas), dissolvendo-os no caso de desordem; pôr em custódia os bêbados durante a bebedice; corrigi-los por vício e turbulência e as prostitutas escandalosas, obrigando-os a assinar termo de bem viver, com a cominação de penas; fazer destruir os quilombos; fazer autos de corpo de delito; interrogar os delinquentes, prendê-los e remetê-los ao juiz competente; ter uma relação dos criminosos para fazer prendê-los; fazer observar as posturas policiais das câmaras; informar o juiz de órfãos sobre incapazes desamparados e acautelar suas pessoas e bens, enquanto aquele não providenciasse; vigiar sobre a conservação das matas públicas e obstar nas particulares ao corte de madeiras reservadas por lei; participar ao presidente da província quaisquer descobertas úteis que se fizessem no seu distrito (minas); procurar a composição das contendas e dúvidas sobre caminhos particulares, atravessadouros e passagens de rios ou ribeiros, sobre uso das águas empregadas na agricultura ou na mineração, dos pastos, pescas e caçadas, sobre limites, tapagens e cercados das fazendas e campos, e sobre os danos feitos por familiares ou escravos; dividir o distrito em quarteirões que não contivessem mais de vinte e cinco fogos. No crime, a sua competência para impor penas ia até o máximo de multa de trinta mil-réis ou um mês de prisão ou três de correção, havendo casa para isso ou oficinas públicas. 
A lei de $1^{\circ}$ de outubro de 1828 , dando nova forma às Câmaras Municipais, atribuiu ao juiz de paz competência privativa para conhecer das multas por contravenção às posturas municipais (art. 88) (RUDYCZ, 2003, p. 7-8).

Como observamos, o Juiz de Paz possuía inúmeras atribuições no seu Distrito, Comarca ou Vila. Para que essas fossem cumpridas, o juiz contava com um pequeno aparato burocrático operacional formado por um escrivão (responsável por expedir autos e outros papéis relativos ao seu juízo), inspetores de quarteirão ${ }^{17}$ (o número variava de acordo com o número de quarteirões $^{18}$ ) e oficiais de justiça. Entre 1832 e 1845, atuaram na Colônia Alemã de São Leopoldo cinco escrivães (oficiais e interinos), cuja responsabilidade "era a de anotar as escrituras" (HUNSCHE, 1979, p. 48). Hunsche cita que para esse período foram eleitos sete escrivães para atuar no Juizado de Paz de São Leopoldo. Entretanto, fazemos uma ressalva nesse dado, pois dois ocuparam o cargo de escrivão mais de uma vez. É o caso de José Ferreira Soares, segundo escrivão interino, atuando entre 21 de 1836 a 20 de fevereiro de 1837, retornando ao posto no ano de 1838. Outro exemplo é de Antônio José da Silva, escrivão interino, que atuou entre 1841 e 1842. Em 1845, encontramos novamente esse nome, porém como escrivão oficial. $\mathrm{O}$ autor não fez nenhuma referência em se tratar da mesma pessoa, porém, acreditamos que seja. Os escrivães do Juizado de Paz de São Leopoldo atuaram em média por um ano, com exceção do primeiro escrivão, Francisco José da Silva, que atuou de sete de janeiro de 1832 até seis de dezembro de 1835, portanto, três anos; e do escrivão interino João da
Silva Paranhos que ficou de 1842 até 1844 . Hunsche salienta que até 1835, ano de atuação do escrivão e tabelião Francisco, os registros eram feitos com regularidade. Dessa data em diante, "vieram outros escrivães, e podem ser constatadas diversas irregularidades: interrupções cronológicas [...]; atuação de diferentes escrivães e displicência na redação" (1979, p. 49).

Após sete anos da fundação da Colônia Alemã de São Leopoldo, foi eleito o primeiro Juiz de Paz, em 1831. Manoel Bento Alves residia na Rua do Passo (atual Rua da Independência) no terreno dois, da quadra trinta e cinco, atualmente em frente ao $\mathrm{Mu}$ seu Histórico Visconde de São Leopoldo. Seu vizinho foi João Batista Orsi, do qual se tornou sócio em um negócio, no ano de 1829. Entretanto, essa sociedade foi desfeita em 1833, conforme consta no próprio livro de Juiz de Paz (ver Tabela 1). Sabemos que Manoel Bento Alves foi o primeiro Juiz de Paz, porém, desconhecemos a informação do período que atuou na colônia, bem como o nome dos demais Juízes de Paz eleitos até 1845. Hunsche justifica que o nome do Juiz de Paz não aparecia nas escrituras, somente quando fosse testemunha ou parte em algum caso.

O Primeiro Livro de Juiz de Paz compõe-se de 147 folhas, nas quais são registrados 145 casos. Esse "há de servir [...] para Nota(s) do Escrivão do Juízo de Paz da Capela Curada de Nossa Senhora da Conceição da Colônia de São Leopoldo" foi à nota introdutória escrita pelo vereador Luís Inácio Pereira de Abreu, no dia $1^{\circ}$ de janeiro de 1832, dando início à vida judicial em São Leopoldo (HUNSCHE, 1979, p. 101). Dos 
145 casos, encontramos registros de escritura de perdão, de liberdade, de doação ou venda de colônias, de hipotecas e de procurações, dentre outras.

Concordamos com Hunsche quando este afirma que os alemães foram vistos com mais frequência no Cartório do Juiz de Paz de São Leopoldo. O autor analisou somente os cem primeiros registros, mas já observava a incidência dos alemães em litígios. Dos 145 casos analisados por nós, 80 foram acionados por alemães (como outorgante e outorgado), 35 por brasileiros e 30 casos mistos, envolvendo alemães e brasileiros. Curiosamente, a maior incidência de casos diz respeito à venda de terras (34 dos 145), venda de morada de casas e terrenos (30 dos 145) e hipotecas (27 dos 145). Lembremos o caso que introduz este artigo, envolvendo Gabriel Hatzenberg e Pedro Wilborn, Felippe Schneider e a sua mulher. O motivo que levou as partes ao Juizado de Paz se refere à troca de terras. Esse dado pode ser um indicativo de que os imigrantes alemães não tinham muito conhecimento e interesse pela agricultura, levando-os a vender suas terras e casas para dedicar-se ao ofício/profissão praticada na Europa ou, ainda, com o intuito de migrar para a região metropolitana.

Vejamos abaixo os casos registrados no Primeiro Livro do Juiz de Paz de São Leopoldo:
Tabela 1. Registros do Primeiro Livro do Juízo de Paz

\begin{tabular}{l|r}
\hline Motivo & Quantidade \\
\hline Arrendamento de colônia & 12 \\
Carta de liberdade & 3 \\
Certidão de sisa paga & 1 \\
Cessão de meia colônia & 3 \\
Distrate de sociedade & 1 \\
Divisão de bens & 1 \\
Doação de terras & 6 \\
Fiança & 1 \\
Hipoteca & 27 \\
Partilha & 3 \\
Perdão & 8 \\
Procuração & 3 \\
Testamento & 1 \\
Tradução de contrato & 7 \\
Troca de terras & 4 \\
Venda de morada de casas e terrenos & 30 \\
Venda de terras & 34 \\
\hline
\end{tabular}

Fonte: HUNSCHE, 1979, p. 68-99.

Conforme evidencia a tabela, foram registrados oito casos envolvendo pedido de perdão. Nos cinco primeiros registros, Inácio Rasch, Conrado Ritzel, João Daniel Haag, João Rohmann e Guilherme Weimann solicitaram perdão por "ofença, ferimentos e contusões" (HUNSCHE, 1979, p. 69) feitos no escravo Miguel, de propriedade de Pedro da Costa Carvalho, no ano de 1832. Os demais casos envolvem alemães e portugueses. Em 1834,

[...] Jacob Beck perdoa a Mateus Doehl as pancadas, ferimentos e contusões recebidos em 26.12.1833 no porto do colono Wetter, no lugar denominado 'atraz da Feitoria Vellha', e desiste de quaisquer acusões a que teria direito (HUNSCHE, 1979, p. 77).

No mesmo ano, Jacob Linck perdoa Martinho Huster por insultos e ataques. "Houve processo e sentença (outubro 1834), sendo Huster obrigado a pagar as custas" 
(HUNSCHE, 1979, p. 79). Em 1836, Manoel Francisco dos Passos perdoava Antônio de Quadros por ferimentos que lhe fez em uma perna no dia 26 do mesmo ano, "na porta de Matheos Gaispich (Geisbuch), pelo qual ferimento ele, queixoso, procedeu o auto de corpo de delito" (HUNSCHE, 1979, p. 225). Segundo Tramontini (2003, p. 109), as queixas, desentendimentos verbais ou físicos significavam um meio de expressar o descontentamento e o desejo de ter seus direitos garantidos.

Os alemães e portugueses também se encontraram no Cartório da Capela de São Leopoldo para tratar de assuntos ligados à hipoteca, à compra e à venda de propriedade. Percebe-se que, ao mesmo tempo em que os alemães e descendentes vendiam a colônia recebida pelo Governo, outros adquiriam novas propriedades na colônia para desenvolver a agricultura. Também era prática comum entre alemães e descendentes, ao invés de vender a sua propriedade, arrendar para portugueses. $\mathrm{O}$ arrendamento, conforme consta no Livro de Juiz de Paz, tinha validade de vinte anos, na qual tanto a propriedade, quanto a casa e as benfeitorias que se encontravam no local eram arrendadas. Em 1833, Pedro Werner e sua mulher Maria Elisabeta arrendaram "uma colônia de campo e mato com duzentas e tantas braças de frente e oitocentas de fundo, sita no Distrito desta Capela, no lugar denominado Feitoria Velha". O negócio foi concluído "pelo preço e quantia de um conto e trezentos e cinquenta mil réis pelo dito tempo" (HUNSCHE, 1979, p. 125).

Nos registros entre alemães e lusos, os nomes de Francisco José de Souza e de Tris- tão José Monteiro aparecem com frequência. O primeiro foi credor em três hipotecas envolvendo alemães como devedores, nos anos de 1832 e 1833. O prazo das hipotecas variava de acordo com o consenso das partes envolvidas (um ano, oito meses, dois meses). Em 1836, Francisco José de Souza comprou "uma morada de casas coberta de telhas, parte dela forrada e assoalhada, cuja casa tem trinta palmos de frente, com fundos competentes [...], sita na Rua do Passo". Essa propriedade foi adquirida pela quantia de "trezentos e vinte e um mil réis", pois os vendedores eram devedores da hipoteca realizada em 1833, junto a Francisco José de Souza. Já o segundo, Tristão José Monteiro, foi um importante comerciante e colonizador da região do Vale do Paranhana. Adquiriu, em 1845, a Fazenda Mundo Novo que compreendia os atuais territórios de Igrejinha, Taquara e Três Coroas e, nesse mesmo ano, vendeu duas propriedades por um conto de réis a João Daudt e Casimiro Algayer, no local denominado Feitoria Velha (HUNSCHE, 1979, p. 125).

Se a função do Juizado de Paz era conciliar as partes envolvidas nos litígios e evitar que houvesse o prosseguimento dos autos ao Juizado competente, acreditamos que tal papel foi desempenhado em São Leopoldo. Não podemos afirmar que todos aqueles que tiveram algum tipo de desavença com um vizinho, com um familiar ou com a justiça compareceram ao Juizado de Paz, pois acreditamos que alguns desentendimentos foram resolvidos por conta própria, isto é, sem a ajuda da justiça. Outros, por sua vez, foram resolvidos através do intermédio do Juiz de Paz. Para finalizar, apesar dos poucos 
trabalhos e pesquisadores que se detenham ao estudo do Juizado de Paz, destacamos a importância dessa figura, bem como desse tipo de fonte, uma vez que permite trazer à tona as tensões e os conflitos dos grupos em diferentes contextos na sociedade; possibilita reconstituir o ambiente político, social e judicial local; e, principalmente, acompanhar o percurso do Juiz de Paz.

\section{Abstract}

The German colony of São Leopoldo was founded in the old Real Feitoria do Linho Cânhamo in 1824. From this date, the colony received an significant contingent of immigrants from different States, Principalities and German Grand Duchies. This diversity represented a new social group that should develop agriculture in southern Brazil and set up a new society. Such a society was not only composed by Germans and their descendants, but also by Luso-Brazilians. Through analysis of the First Book of Justice of the Peace of the German Colony of São Leopoldo covering the years 1832 until 1845, we paid attention to the reasons why the residents of São Leopoldo sought justice.

Keywords: German colony of São Leopoldo. First Book of Justice of the Peace. Justice.

\section{Resumen}

La Colonia Alemana de São Leopoldo fue fundada en la antigua Real Feitoria do Linho Cânhamo, en 1824. A partir de esta fecha, la colonia recibió un núme- ro significativo de inmigrantes de diferentes estados, principados y ducados Grandes Alemanes. Esta diversidad representa un nuevo grupo social debe desarrollar la agricultura en el sur de Brasil y crear una nueva empresa. La sociedad está compuesta no sólo de los alemanes y sus descendientes, sino también por los luso-brasileños. A través del análisis del Primer Libro de Justicia de la Paz y la Colonia Alemana de São Leopoldo que abarca los años 1832 a 1845, nos fijamos en las razones por las cuales los habitantes de São Leopoldo en busca de justicia.

Palabras clave: Colonia alemana de São Leopoldo. Primer Libro de Juez de Paz. Justicia.

\section{Notas}

1 HUNSCHE, Carlos H. Primórdios da vida judicial de São Leopoldo. Porto Alegre: EST São Lourenço de Brindes, 1979.

2 Luiza Ruppenthal, natural de Adesbach, Altenburg, Alemanha, contraiu matrimônio com Peter Wilborn no Brasil, pois na lista de saída aparece como solteiro. Dessa união nasceu João Adão Augusto que se casou com Luiza Mertens. Conforme mapa estatístico de 1886, Augusto residia na estância denominada Quatro Colônias, no terceiro quarteirão, do quarto distrito da Vila de São Leopoldo - Campo Bom. Nesse local, Augusto possuía uma propriedade com seis gados vacum, dois idem cavalares e 18 idem cordum. AHRS, Fundo Polícia, maço 35. DREHER, Livro de Registros da Comunidade Evangélica de São Leopoldo (CD-ROM), (ROSA, 2005, p. 26).

3 O nome de Peter Wilborn figura na listagem dos presidiários da Casa de Correção e da prisão de Dömitz embarcados para o Brasil em 6 de dezembro de 1824. Peter tinha 44 anos de idadequando foi encaminhado à Casa de Correção por ter cometido furtos, em 20 de novembro de 1820. Ex-carniceiro e natural de Gr. Poserin foi condenado à prisão perpétua, sendo mantido pela caixa da instituição. Faleceu em Quatro Colônias em 31 de dezembro de 1848. Listagem dos presidiá- 
rios da Casa de Correção e da Prisão de Dömitz embarcados para o Brasil em 6 de dezembro de 1824. In: Mecklenburg Geheimes und Haupt-Archiv Schwerin MLHA Schwerin Kabinett I - Sig. 54: Acta, die zweite Abführung von Stock- und Zuchthausgefangenen nach Brasilien betreffend, fl 26. Tradução de Martin Norberto Dreher.

4 Casado com a filha da suplicante, de nome Carolina Wilborn.

5 APERS, São Leopoldo, Ação de Libelo, Cartório do Cível e Crime de São Leopoldo, maço 16, 1857, n. 673.

6 Foram vendidos por Felippe Schneider, um cavalo com um par de arreios, uma vaca mansa com cria, uma outra vaca com cria, dois terneiros, dezessete porcos grandes e pequenos, várias ferramentas de sapateiros, onze taboas de pedra, vários livros religiosos e 32\$000 em dinheiro.

7 "Felippe Schneider e sua esposa possuem um quarto de colônia cita no lugar denominado Quatro Colonias, Freguesia de Nossa Senhora da Conceição, dividindo-se pelo Norte com terras de Christiano Weinöhl, pelo Sul com os fundos da colônia de Campo Bom, pelo Leste com terras de Felippe Deiner e pelo Oeste com terras de Simião Kappel". Villa de São Leopoldo, 8 de agosto de 1855. (APERS, São Leopoldo, Ação de Libelo, Cartório do Cível e Crime de São Leopoldo, maço 16, 1857, n. 673).

8 APERS, São Leopoldo, Ação de Libelo, Cartório do Cível e Crime de São Leopoldo, março 16, 1857, n. 673.

9 APERS, São Leopoldo, Ação de Libelo, Cartório do Cível e Crime de São Leopoldo, março 16, 1857, n. 673.

10 "O Código do Processo criou em cada termo um juiz municipal a ser nomeado pelos presidentes das Províncias, pelo prazo de três anos, dentre os indicados pelas Câmaras Municipais em listas tríplices, os quais deviam ser bacharéis ou advogados hábeis. 44 Suas atribuições eram substituir os juízes de direito nos termos; executar as sentenças; exercitar cumulativamente as atribuições policiais; conceder habeas corpus; processar os feitos cíveis até a sentença exclusive. 45 Nos seus impedimentos, os juízes municipais eram substituídos interinamente por pessoa nomeada pela Câmara (art. 33)" (RUDYCZ, 2003, p. 18).

11 "Os juízes de direito eram nomeados pelo Imperador, deviam ser bacharéis, com prática de pelo menos um ano no foro, preferindo-se os que tivessem servido como juízes municipais ou promotores. De acordo com a Constituição, tinham a garantia da vitaliciedade ("perpétuos"), mas não a da inamovibilidade, significando que po- diam ser removidos de um lugar para outro, na forma da lei. Sua principal atribuição era presidir o Conselho de Jurados, aplicar a lei aos fatos (art. 46) e julgar os feitos cíveis que não fossem da competência de outros juízes. Era ainda da sua competência conceder fiança aos réus sujeitos ao processo perante o júri; conhecer do recurso das fianças concedidas ou negadas pelos juízes de paz, bem como da decisão desses juízes que julgasse perdida a quantia afiançada; conceder habeas corpus; proceder a qualquer diligência que entendesse necessária e julgar os feitos cíveis que ultrapassassem a competência do juiz de paz e dos juízes municipais. Os juízes de direito exerciam jurisdição na comarca, que eram circunscrições compostas de vários municípios, nas quais funcionavam, ao tempo da Colônia, as justiças dos ouvidores; nos seus impedimentos, eram substituídos pelos juízes municipais" (RUDYCZ, 2003, p. 17).

12 Tanto o Juiz Municipal quanto o Promotor Público era escolhido um porser, "nomeado pela Corte e Presidentes de Província, por indicação de lista tríplice das câmaras municipais, preferencialmente graduados em Direito" (VELLASCO, 2004, p. 121).

13 De acordo com o Código do Processo Criminal do Império do Brasil de 1832, a Comarca teria um Juiz de Direito (máximo 3, nomeados pelo Imperador) e Chefe de Polícia (1 dos juízes nas cidades mais populosas); o Termo era composto por um Conselho de Jurados (alistamento), Juiz Municipal (nomeados pela Corte e Presidentes de Província), Promotor Público, Escrivão de execuções e Oficiais de Justiça; o Distrito escolheria Juiz de Paz (eleito), Escrivão (nomeado pelas Câmaras), Inspetores de Quarteirão e Oficiais de Justiça. (VELLASCO, 2004, p. 122).

14 "Entre as atribuições judiciais figuram: a conciliação das partes da demanda 'por todos os meios pacíficos que estivessem ao seu alcance', o julgamento de pequenas demandas, cujo valor não excedesse a $16 \$ 000$ réis; fazer comparecer à sua presença o delinquente que lhe fosse indicado para interrogá-lo e às respectivas testemunhas sobre o fato incriminado, prendendo-o e remetendo-o ao juiz criminal; informar ao juiz de órfãos sobre menores abandonados; fazer comparecer à sua presença os desobedientes, lavrando o respectivo termo, ouvindo-os e podendo condená-los à multa de 2-6 dias de prisão, quando não tivessem meios de pagar a multa pecuniária; impor, no máximo, a multa de $30 \$ 000$ réis e prisão até um mês na Casa de Correção e, na falta, em edifícios públicos, até três meses; o termo de bem viver e 
sentença que impusessem a pena só teriam lugar depondo duas a três testemunhas e ouvida a parte" (HUNSCHE, 1979, p. 33).

15 "Entre as funções administrativas do juiz de paz figuram: fazer observar as posturas municipais, impondo as respectivas penas aos que as violassem; vigiar sobre a conservação das matas e florestas públicas; participar ao Presidente da Província as descobertas dos reinos mineral, vegetal e animal que ocorressem; compor todas as contendas sobre os caminhos particulares, atravessadouros, passagens de rios ou ribeiros, uso de águas empregadas na agricultura e mineração, pastos, pescas, caçadas, limites cercados de fazendas e campos, e danos causados por escravos, familiares ou animais domésticos; dividir os distritos em quarteirões de 25 fogos, nomeando para cada qual um oficial que o avisasse de todos os acontecimentos e cumprisse as ordens" (HUNSCHE, 1979, p. 33 - 34).

16 "As funções policiais se concretizavam em fazer separar os ajuntamentos perigosos ou vigiá-los; em caso de motim, empregar a força pública, mas somente depois dos amotinadores terem sido admoestados pelo menos três vezes para se recolherem às suas casas; pôr em custódia os bêbados durante a bebedice; evitar rixas; exercer inspeção sobre vadios e mendigos no sentido de fazê-los trabalhar; destruir quilombos e evitar sua formação; ter uma relação dos criminosos para prendê-los quando estivessem no seu distrito, podendo, em seguimento deles, penetrar em outros distritos" (HUNSCHE, 1979, p. 34).

17 No artigo "'Uma autoridade na porta das casas:' os inspetores de quarteirão e o policiamento no Recife do século XIX (1830-1850)", Wellington Barbosa da Silva define quem era, como era escolhido e a função do inspetor de quarteirão. "Os inspetores de quarteirão eram selecionados pelos juízes de paz entre a população dos distritos e, então, propostos à Câmara Municipal - que se encarregava da aprovação de seus nomes. Sendo considerados como "uma autoridade na porta das casas", eles deveriam ser escolhidos entre os cidadãos maiores de 21 anos, que soubessem ler e escrever e que gozassem de boa reputação em seus quarteirões - não devendo, ainda, estarem qualificados para o serviço ativo da Guarda Nacional. Recebiam uma parcela considerável de poder para coibir a prática de atos delituosos - zelando pelas propriedades e pelo sossego de todos aqueles que moravam no quarteirão. Para isso, como determinava o Código de Processo Criminal (art. $120, \S 20)$, eles tinham autoridade para efetuar prisões em flagrante, para admoestar e, até mes- mo, caso não conseguissem resultado prático com as admoestações, para obrigar a assinar "termos de bem viver" a todos aqueles que, de uma forma ou de outra, viviam pelas ruas ofendendo os bons costumes e perturbando o sossego público, tais como: vadios, mendigos, bêbados, desordeiros e prostitutas. Diariamente, tinham a obrigação de enviar para os juízes de paz uma parte circunstanciada dos acontecimentos ocorridos em suas respectivas áreas de jurisdição. Em suma, os inspetores eram a primeira instância do policiamento em cada aglomerado urbano, fosse este uma vila ou uma cidade" (SILVA, 2007, p. 29).

18 O quarteirão era a menor unidade administrativa do município, sendo composta por um conjunto de 25 casas ou fogos. Cada três quarteirões formava um Distrito. (SILVA, 2007, p. 29).

\section{Referências}

CAMPOS, Adriana Pereira. Juízes de fato: participação e administração da justiça local. Dimensões, v. 28, n. 28, 2012, p. 103-122. Disponível em: <http://www.periodicos.ufes. br/dimensoes/article/viewFile/4311/3371>. Acesso em: 20 jun. 2013.

CARDOSO, Sônia Weber. O policiamento em São Leopoldo. In: . São Leopoldo Antigo: a cidade brasileira de colonização Alemã. São Leopoldo: EST, 2007.

CODA, Alexandra. A atuação do Juiz de Paz na esfera criminal Porto Alegre (1827-1841). In: Anais do X Encontro Estadual de História. Santa Maria, 2010. Disponível em: <http:// www.eeh2010.anpuhrs.org.br/resources/ anais/9/1279312736_ARQUIVO_Artigo_ Anpuh2010.pdf>. Acesso em: 20 jun. 2013.

. Os eleitos da Justiça: a atuação dos juízes de paz em Porto Alegre (1827-1841). 2012. Dissertação (Mestrado em História) - Universidade Federal do Rio Grande do Sul, Porto Alegre, 2012.

GINZBURG, Carlo. O nome e o como: troca desigual e mercado historiográfico. In: . A micro-história e outros ensaios. Lisboa: DIFEL; Rio de Janeiro: Bertrand Brasil, 1989a. p. 169-178. 
Sinais: raízes de um paradigma indiciário. In: Mitos, emblemas e sinais: morfologia e história. São Paulo: Companhia das Letras, 1989b. p. 143-179.

GROSSO, Carlos Eduardo Millen. A cidade, os crimes e o poder público: um estudo sobre a construção social da criminalidade na Porto Alegre da virada do século XIX (1890-1909). In: IX ENCONTRO ESTADUAL DE HISTÓRIA Vestígios do passado: a história e as suas fontes. 2007, Porto Alegre. Anais... Porto Alegre, 2007. Disponível em: <http:/ / eeh2008.anpuh-rs.org.br/site/anaiseletronicos/1212344910_ ARQUIVO_anpuhrs-artigo.pdf>. Acesso em: 21 out. 2011.

HUNSCHE, Carlos H. O biênio 1824/25 da imigração e colonização alemã no Rio Grande do Sul (Província de São Pedro). 2. ed. Rev. e ampl. Porto Alegre: A Nação, 1975.

O ano de 1826 da imigração alemã no Rio Grande do Sul (Província de São Pedro). Porto Alegre: Metrópole, 1977.

Primórdios da vida judicial de São Leopoldo. Porto Alegre: Escola Superior de Teologia, 1979.

LEVI, Giovanni. A Herança imaterial: trajetória de um exorcista no Piemonte do século XVII. Rio de Janeiro: Civilização Brasileira, 2000.

Sobre a Micro-História. In: BURKE, Peter (Org.). A escrita da história: novas perspectivas. São Paulo: Ed. da UNESP, 1992. p. 133-162.

MATOS, Leandro Pereira. Entre vozes e discursos: a análise da documentação criminal para o estudo da imigração em Juiz de Fora no final do século XIX. In: II COLÓQUIO DO LAHES, 2008, Juiz de Fora. Anais... Juiz de Fora, 2008. Disponível em: <www.ufjf.br/ lahes/files/2010/03/c2-a32.pdf>. Acesso em: 21 out. 2011.

MOEHLECKE, Germano Oscar. São Leopoldo: contribuição à história da vida política e administrativa (1824-2010). São Leopoldo: Oikos, 2011.
. A Câmara ao longo dos Tempos. In: SILVA, Haike Roselane Kleber da; HARRES, Marluza Marques. A história da Câmara e a Câmara na história. São Leopoldo: Oikos, 2006. p. 25-44.

MÜHLEN, Caroline von. Degredados e imigrantes: trajetórias de ex-prisioneiros de Mecklenburg-Schwerin no Brasil Meridional (século XIX). Santa Maria: Ed. da UFSM, 2013.

NASCIMENTO. Joelma Aparecida do. Herança e adaptação em uma vila do Império: Juízes de Paz, diversidade econômica e hierarquias sociais. Mariana, Brasil (1827-1841). In: XXXI ENCONTRO DA ASSOCIAÇÃO PORTUGUESA DE HISTÓRIA ECONÔMICA E SOCIAL. 2011. Disponível em: <http:/ / www4.fe.uc.pt/ aphes31/papers/sessao_5f/joelma_nascimento_paper.pdf>. Acesso em: 20 jun. 2013.

Eleições municipais e os primórdios da administração da Justiça no Brasil: o caso do juizado de paz nas Minas (1827-1841). Revista Brasileira de História \& Ciências Sociais. v. 2, n. 4, dez. 2010a. Disponível em: <http:/ /www. rbhcs.com/index_arquivos/Artigo.Juizadodepaz.pdf>. Acesso em 20 jun. 2013.

Os "homens" da administração e da justiça no império: eleição e perfil social dos juízes de paz em Mariana, 1827-1841. 2010. Dissertação (Mestrado em História) - Universidade Federal de Juiz de Fora, Juiz de Fora, 2010b.

PICCOLO, Helga Iracema Landgraf. O império brasileiro e a administração municipal. $\mathrm{O}$ caso de São Leopoldo (1824-1846). In: SILVA, Haike Roselane Kleber da; HARRES, Marluza Marques. A história da Câmara e a Câmara na história. São Leopoldo: Oikos, 2006. p. 45-55.

RAMOS, Eloísa Helena Capovilla da Luz. Tensões e sociabilidade nas relações entre a câmara municipal de São Leopoldo e a comunidade. In: SILVA, Haike Roselane Kleber da; HARRES, Marluza Marques. A história da câmara e a câmara na história. São Leopoldo: Oikos, 2006. p. 124-135. 
RODYCZ, Wilson Carlos. O juiz de paz imperial: uma experiência de magistratura leiga e eletiva no Brasil. Justiça \& História, Porto Alegre, v. 3, n. 5, p. 35-72, jan./jun. 2003. Disponível em: <http://www.tjrs.jus.br/export/ poder_judiciario/historia/memorial_do_poder_judiciario/memorial_judiciario_gaucho/revista_justica_e_historia/issn_16765834/v3n5/doc/02-Wilson_Rodycz.pdf.>. Acesso em: 20 jun. 2013.

SALES, Izabella Fátima Oliveira de. A micro - história e suas contribuições para os estudos das minas setecentistas. In: II COLÓQUIO DO LAHES, 2008, Juiz de Fora. Anais... Juiz de Fora, 2008. Disponível em: <www.ufjf.br/ lahes/files/2010/03/c2-a26.pdf>. Acesso em: 21 out. 2011.

SILVA, Edna Mara Ferreira da. A ação da justiça e a as transgressões da moral processos crime em Mariana - 1747-1830. In: I COLÓQUIO DO LAHES, 2005, Juiz de Fora. Anais... Juiz de Fora, 2005. Disponível em: <www.ufjf.br/ lahes/files/2010/03/c1-a17.pdf>. Acesso em: 21 out. 2011.

SILVA, Haike Roselane Kleber da. Fontes para a história da câmara municipal de vereadores de São Leopoldo. In: SILVA, Haike Roselane Kleber da; HARRES, Marluza Marques. A história da Câmara e a Câmara na história. São Leopoldo: Oikos, 2006. p. 15-24.

SILVA, Mozart Linhares da. Do Império da lei às grades da cidade. Porto Alegre: EDIPUCRS, 1997.

SILVA, Wellington Barbosa da. Uma autoridade na porta das casas: os inspetores de quarteirão e o policiamento no Recife do século XIX (18301850). Disponível em: <http://www.pm.al. gov.br/intra/downloads/bc_policial/pol_06. pdf>. Acesso em: 20 jun. 2013.

SOUZA. Alexandre de Oliveira Bazílio de. Das urnas para as urnas: o papel do Juiz de Paz nas eleições no fim do Império (1871-1889). 2012. Dissertação (Mestrado em História) - Universidade Federal do Espírito Santo, Espírito Santo, 2012.
TRAMONTINI. Marcos Justo. A organização social dos imigrantes: a colônia alemã de São Leopoldo na fase pioneira 1824-1850. São Leopoldo: Ed. Unisinos, 2003.

VELLASCO, Ivan de Andrade. O juiz de paz e o código do processo: vicissitudes da justiça imperial em uma comarca de Minas Gerais no século XIX. Revista Justiça e História. Porto Alegre, v. 3, n. 6, p. 65-95, mês abreviado, 2003. Disponível em: <http://www.tjrs.jus.br>. Acesso em: 20 jun. 2013.

As seduções da ordem: violência, criminalidade e administração da justiça: Minas Gerais, século 19. São Paulo: Edusc/Anpocs, 2004. 